Prof. Dr. Rouhollah Khodabandelou \& Prof. Dr. Azadeh Amoozegar \& Zahra Pourjafarian

Volume (4) No. (1) 2021

COVID-19 and online behaviors in higher education: A comparative study of an Iranian, Omani and Malaysian Universities

Prof. Dr. Rouhollah Khodabandelou \& Prof. Dr. Azadeh Amoozegar \& Zahra Pourjafarian 
Prof. Dr. Rouhollah Khodabandelou \& Prof. Dr. Azadeh Amoozegar \& Zahra Pourjafarian 2021 المجلد (4) العدد (1) 2021 20

\title{
COVID-19 and online behaviors in higher education: A comparative study of an Iranian, Omani and Malaysian Universities
}

Rouhollah Khodabandelou $(\mathrm{PhD})$

PhD, Department of Instructional and Learning Technology, College of Education, Sultan Qaboos University, Muscat, Oman

$$
\text { r.bandelou@squ.edu.my }
$$

Azadeh Amoozegar (PhD)

$\mathrm{PhD}$, Centre of Post Graduate Studies, Limkokwing University of Creative

Technology, Kuala Lumpur, Malaysia

azadeh.amoozegar@limkokwing.edu.my

Zahra Pourjafarian

PhD Student, Department of Educational Studies, Islamic Azad University, Tehran, Iran

zahra.purjafariyan@gmail.com

Received in 4th February 2020

Accepted in 3rd August 2020

\begin{abstract}
The outbreak of the COVID-19 in early 2020 caused most of higher learning institutions to close the campuses and forced them to initiate online teaching and learning. Since, regular classrooms are temporarily empty, this paper focuses on the online education experiences of three Asian universities during the COID-19 pandemic. For the purpose of the current study from each case, Up to Six (6) specific instructional strategies are presented in each case. The strategies summarized current online teaching experiences which can be used by other faculty members in similar circumstances.
\end{abstract}

Keywords: Covid-19, Higher education, Online Teaching, Oman, Iran, Malaysia 


\section{Introduction}

The best investment that can be made is in education. Education raises the potential of the individual through value-added means, which, in turn raises the potential of businesses and economies to perform well (Mahathir, 2019). For this reason, the COVID-19 pandemic is a quintessential adaptive and transformative challenge in particular in education. During this special circumstance governments effort to utilize technology in support of remote learning, distance education and online learning (Reimers \& Schleicher, 2020). In this regards, since the early 2020, most of the higher education institutions have been experiencing an unprecedented massive "migration" from traditional in-class face-to-face education to online education (Bao, 2020). For this reason, the majority of the higher education institutions have been recommended to stablished "nonstop teaching and learning" policy. Online teaching mood in this respect a chance for delivering contents.

Nowadays, higher learning institutions are in the fast-track process to adopt their conventional teaching and learning methods to different types of virtual learning mood including synchronous and asynchronous learning delivery formats in order to reach approximately 1.5 billion students who are not allowed to physically attend their classes (UNESCO, 2020).

Although, university lecturers and instructors are being bombarded with advice on how to design online teaching and learning activities (Surma \& Kirschner, 2020), but little research attention has been paid to documenting and analyzing attempts of education systems moving quickly and at scale to provide online learning when all or many schools are closed (World Bank, 2020). Related 'good practices' are considered rare, and on the whole, activities and initiatives of these sorts are poorly documented, especially when it comes to the needs of learners and education systems across the so called 'developing world'. Indeed, the main objective of the current case study research is to review 3 Asian higher learning institutions online experiences during Covid-19 in order to offer high-level guidance and 'rules of thumb' for policymakers forced to make related decisions in fast moving, very challenging circumstances with little guidance or 
relevant experience. In this brief note we will also provide some general comments and guidelines to policy makers in order to implement an effective and efficient policies.

\section{Case Context and Focus}

\section{A. Sultan Qaboos University- Oman}

Early, decisive and clear action taken by the government of Oman to combat COVID19 has had a dramatic impact on containing and slowing the spread of the virus nationwide. Clear and regular communication with the general public in multiple languages, with the "Oman vs COVID-19" initiative as its linchpin (World Economic Forum, 2020). In line with this government policy, all higher education institutions have adopted the concept of online learning. However, since the beginning of the pandemic in Oman in March 2020, SQU has suspended all its teaching and teaching and learning for one month. Due to unexpected outbreak COVID-19 the supreme committee of COVID-19 in SQU has decided to continue its teaching and learning activities in April via Online mode. The university then has launched its online courses by using commercial LMS -Moodle. All faculty members were requested to open a class for their courses in Moodle platform.

\section{B. Limkokwing University of Creative Technology - Malaysia}

The Malaysian higher education system over the past few decades has made significant gains in many dimensions such as institutional quality (Ganapathy, 2016). In this respect, Limkokwing University of Creative Technology (LUCT), played an active role in creating an environmental education that is conducive for the development of academic and institutional excellence and to generate individuals who are competent, innovative and of noble character to serve the needs of the nation and the world.

LUCT is a private international university which was established in 1991. The university has a presence across three continents with over 30,000 students coming from more than 150 countries. With its main campus in Malaysia, Limkokwing university is home to 9,500 students and offers education programs in foundation, diploma, degree, master, and PhD level. The education system in LUCT is based on traditional and modern classroom education and requires the students to attend the university classes, but in response to the COVID-19 pandemic, the university classes 
were suspended for one week rather than school closures from March 18 to March 25 and switched to online learning to arrest the spread of COVID-19. The university announced the cancelation of various exams at different levels and the traditional examinations are being replaced with other forms of assessments following the Movement Control Order (MCO) being enforced.

\section{Alzahra University - Iran}

Founded in 1964, Alzahra University is a one of the prominent institutions of higher education in Iran dedicated to educating learned and lively women. During the past 40 years, the university has tremendously changed and developed and is now offering various degree programs at undergraduate and graduate levels. Same as other Iranian higher education institutions, at first, the Covid-19 was not taken seriously. Before the pandemic, online teaching methods were not as widely accepted among students, faculty members, and university officials. Most of the lecturers believed that traditional methods are more effective, efficient and engage students. In addition, in some faculties some of the academic members were not trust to online platform especially in assessment and evaluation. They also believed that the flexibility of the face to face instruction is more than Online mode. In this regard, the university did not have the necessary foresight and preparation for this way of teaching. The outbreak of the COVID-19 has inevitably led to paying attention to this issue. After the outbreak, students, faculties, and officials at the university have shifted to online platform.

\section{Instructional Strategies}

Based on observations of online teaching at three Asian universities -SQU, LUCT and Alzahra University, this case study classifies some instructional strategies which have been implemented by the universities to improve students' performance and increasing educational justice in these universities.

\section{A. Sultan Qaboos University}

\section{1- First, making emergency preparedness plans}

Since all the programs and courses were switched to online instruction mode, it has been conducted introductory meetings in each department in order to prepare basic infrastructures how to switch to online mode. Because, SQU managers believe that the 
computer servers may not be able to host such a large scale of new users, the online education platform may often shut down because of overload. At the same time, all faculty members were requested to prepare their Emergency Teaching Plans (ETP) for the rest of the semester (because already 7 weeks of the semester conducted by face to face mode). They need to restructure their lesson plans and move to online mode. In this regard, all faculty members had 1-week time to change their syllabus and lesson plans.

\section{2- Second, Revised course syllabus}

A complete online course requires an elaborate lesson plan design, teaching materials such as audio and video contents, as well as technology support teams (Bao, 2020). Therefore, in the second step all faculties requested to review and revised their course syllabus and lesson plans to meet this circumstance.

\section{3- Third, Dividing the teaching content into smaller units}

Due to the internet penetration and speed which still seems to be in the evolving stages, faculty members requested to divide teaching materials to smaller units in order to help students focus and to ensure that students concentrate on online instruction. Another reason for reasonably breaking down the content was ensuring a clear knowledge structure in the curriculum

\section{4- Forth, Home based learning}

In Oman, despite the progress in student access, the education system continued to exhibit poor student outcomes. There is a severe lack in the use of student-centered learning approaches (Al Shabibi \& Silvennoinen, 2018). In order to fill this gap, one suggestion is promoting and highlighting the home-based learning approach. During the pandemic, university lecturers requested to design and develop activities that support home based-learning.

\section{5- Fifth, Classroom Management:}

It has been selected a specific strategy for classroom management. Faculty members requested to choose the time to consider a series of strategies and try to adhere to them to reduce confusion among students. For example: 1) Selecting exact hours of the day to send content materials, 2) Connecting with students through electronic tools such as 
WhatsApp and Online discussion forums, and 3) Selecting specific days to give students a break in order to make their minds fresh.

\section{6- Maintaining the student-instructor interaction:}

It is highly important that students hear their teachers' voices rather than reading a text message from them once in a while in a remote-teaching method. Alternatively, if possible, teachers should have at least one synchronous session per week using the available tools. Moreover, it is important that students communicate with each other through class discussions. Therefore, designing class activities that can enable such human interactions is crucial for learning during these times. Teachers and students are used to face-to-face teaching and learning, and a sudden stop in human interaction can be detrimental to your students' learning. To help facilitate the human-to-human interaction continuity, we provided links to useful tools that teachers can use in Iran to communicate with their students using video conferencing or at least via voice messaging.

\section{B. Limkokwing University}

\section{1- First, Preparedness}

On March 18, LUCT issued a series of announcements, including an early notice for educators to prepare for online lessons with students allowed to follow such classes from their residence to ensure student's education would not be neglected during this period, and that all practical and out-of-classroom activities would be postponed while lab research could continue on. Hence, with a variety of online education tools, it was realized that Google Classroom brings the benefits of paperless sharing and digital collaboration to classrooms. In fact, Malaysia has emerged as the second-largest country to use Google Classroom for online teaching during the MCO period (Education International, 2020).

\section{2- Second, Choosing Specific platform}

Google Classroom has been selected as Learning Management System (LMS). In compare to other LMSs that have been popular over the past decade, Google Classroom is amazingly simple. It is Cloud-based and accessible from anywhere with a connection. Students can share assignments and work from home together to complete them. Also, 
setting up a new classroom does not take much time or expertise. However, educators started creating a new classroom for each module in Google Classroom and assigning a permanent link in Google Meet by using google calendar for videoconferencing. The classroom links were sent to the students through email or WhatsApp group. In such a structure, the student must use one link to enter the virtual class and wait for a teacher and other students to join. Hence, Projects, group work, presentations and assessment can be done even collaboratively online in real-time with Google Classroom and Meet.

\section{3- Third, Time Management}

LUCT expected teaching problem to occur with differences in time zone as students who were back in their countries had to attend virtual classes based on Malaysian time. In this respect, lecturers managed to use calendaring tool such as Google Calendar to schedule routines, classes and deadlines that help them to achieve their daily goals and objectives. Moreover, the university had issued guidelines for the alternative methods to ensure that students achieve the learning outcomes for the subject and course. According to the guideline, lecturers have been supposed to shoot videos and share them in WhatsApp group or communicate with them via WhatsApp video/ audio calls or utilizing internet communication platform such as Google Meet or Zoom to connect with the above-mentioned students individually. However, students have been allowed to reach out to their respective Program Leaders or Lecturers via Email and WhatsApp group, if they have questions about course material, due dates, or any other concerns.

\section{4- Forth, Applying remote teaching and learning}

As the Centre of Postgraduate Studies has suspended all non-essential face-to-face meetings, supervisory teams should take steps to support the research students during the lockdown remotely via Google Meet, WhatsApp call and comment in Microsoft words. Students expected to complete their corrections remotely and send the amendment thesis to PGC research team via email in replace of a printed copy. The research team, who are working remotely, will check the student's status and appoint the examiners. They will then forward the e-thesis to the examiners. Viva takes place with the students and examiners participating remotely. Meetings should be arranged 
Prof. Dr. Rouhollah Khodabandelou \& Prof. Dr. Azadeh Amoozegar \& Zahra Pourjafarian Volume (4) No. (1) 2021

via suitable meeting software. Documents should be shared electronically in advance so that the time can be used to best effect.

Video conferencing tips:

- Using a professional video conference system, e.g. Google Meet

- Using headphones/headset may make it easier to hear conversations clearly

- Mute when you are not speaking to minimize background noise.

\section{5- Fifth, Online Viva}

The viva is one of the most stressful moments in the master journey. However, it is an important one as it allows students to defend their thesis. Masters usually defend their thesis on university grounds, in the same room with their examiners. But because of university closures and the need for social distancing, Limkokwing recognized that viva voce examinations may be disrupted during the time of altered working conditions, and reduced ability to travel due to COVID-19 pandemic. In its meeting of 4 April 2020, the university has agreed to facilitate the adoption of online viva. In this respect, the admin of the faculty used Google Calendar to create an event, then a video meeting in Google Meet added to the calendar by inviting students to the event.

\section{Alzahra University}

\section{1- First, preparedness}

Along with increasing the severity and prevalence of the pandemic in Iran and after three face-to-face instructions, various programs were requested to define a mechanism for the rest of the semester. First, the possibility of using WhatsApp and other social network applications to deliver learning contents were examined. then, it was decided to provide the guidelines how to implement social network applications in teaching and learning through the university website. In this respect, the university provided "Regulations for online learning". In this document all necessary information were provided for effective implementation of this delivery system in teaching and learning process.

In addition to use social network, the university used its LMS platform and all lecturer requested to develop a class for their courses in this platform. Students and faculty 
members enter the classroom with their usernames. Students' attendance in the classroom is recorded as soon as they login into the course. Each student has a microphone through which he or she can ask questions or participate in discussions. It is possible to control the presence of students only through regular and continuous dialogue between the instructor and students. The number of the class sessions is similar to the number of real course sessions. All courses are held online.

\section{2- Second, revised the lesson plan and teaching and learning design:}

Before starting the online mode, all instructors requested to revise their lesson plans and fit with this special circumstances. Based on what was going on during the first month of the university closer, creating instructional videos was a common way of teaching among instructors. While this was a great strategy, simple tips for creating a high-quality instructional video using the most ordinary equipment (e.g., mobile phones and home equipment) presented to the lecturer during their regular workshops in every day. For example: plan to divide a long instructional video into smaller chunks under 10 minutes, have a consistent structure in instructors' videos (e.g., objectives, content delivery, examples, and summary), stay toward the light source rather than turning your back toward the light source, and use a microphone. The university also provided some details regarding how to keep the video file sizes low so students would not need a high-speed Internet or they do not have to pay more for a data plan.

\section{3- Third, deliver content and teaching material}

Lecturers were encouraged to consider including students in designing the best delivery methods to ensure effective, efficient, engaging and meaningful learning experience for them. In this regard, all lecturers requested to inform the students about the scheduling of activities before hand to ensure an efficient teaching and learning delivery. Students also be informed about:

- teaching and learning activities that will be done and important dates to be followed;

- $\quad$ types of assessment and detailed weightage for each assessment; and duration and scheduling of synchronous type of assessment. 
Delivery of instruction was done in two ways: synchronous or asynchronous learning interactions.

\section{4- Forth, designing class activities}

In this new situation, instructors need to be creative and design activities that can engage students at home. For example, the university suggested that instructors can create social media challenges. In these challenges, students can enroll in problembased learning activities. Then, students could post their answers on social media. Such activities can be very engaging. Moreover, university recommended that instructors think of creative ideas to boost student's motivation, sense of community, and generally their affective states.

lecturers were encouraged to prepare 3 components:

- Presentation of online content (i.e. learning materials) - in various forms e.g. online (live) lectures, pre-recorded presentations, YouTube videos, links to webpages related to topic of learning, etc.

- Learners' activities - minimum of 1 activity per topic; and

- $\quad$ Assessment - minimum of 1 assessment per topic.

In the Synchronous teaching and learning activities lecturers may allowed:

- Conduct live online lectures; and/or

- Invite guest speaker(s) to the online session.

In these sections, they requested to get students to actively participate in the session by encouraging them to: Write ideas, comments, sharing resources using the chat box; Sharing ideas and comments verbally; and/or Present their works to everyone in class using the screen sharing feature.

In the Asynchronous teaching and learning activities lecturers encouraged: Prerecorded lectures; Screencasting i.e. video recording of computer screens; and/or Slidecasting i.e. audio podcasts that are combined with slideshow

\section{5- Fifth, Student assessment}

Instructors in each course can conduct formative and summative assessment in order to measure students' learning. Intensive or final assessment is performed in all course to measure students' learning. On the specified date for each exam, the instructor uploads 
the exam questions to the LMS. Students login to the system start answering the questions, then send to the lecturer portal. Exam questions are in line with curriculum, topics, purpose, and content of each course.

\section{Conclusion}

The COVID-19 pandemic has substantial education, social, and economic impacts in all communities. Having access to quality and affordable education services everywhere is the rights of all these communities including rich and poor. COVID-19 provided special opportunity to think about these ideas. In this paper we reviewed 3 university cases in 3 Asian countries to see their experiences during the pandemic.

Observations showed that Iran and Oman cases do not have strong basic infrastructure to run online teaching such as technical infrastructure, high-speed internet, and access to tools and equipment for students and professors (laptops, mobile phones, etc.). Online delivery format of content at these universities is still in its infancy compared to universities in developed countries. To fill this gap, it is necessary to develop the students and instructor's information technology skills, expand the quantitative and qualitative technologic infrastructure, and strengthen the Internet infrastructure. The universities are not in a good position in terms of administration and support for this method.

We observed that the simple and superficial combination of educational elements with the technologic facilities and tools without sufficient knowledge of the capabilities and features of the online learning environment can lead to a decrease in the quality of learning, dissatisfaction, and academic failure. 


\section{References:}

- Al Shabibi, A. S., \& Silvennoinen, H. (2018). Challenges in Education System Affecting Teacher Professional Development in Oman. Athens Journal of Education, 5(3), 261-282.

- $\quad$ Bao, W. (2020). COVID-19 and online teaching in higher education: A case study of Peking University. Human Behavior and Emerging Technologies, 2(2), 113-115.

- $\quad$ Education International. (2020). Malaysia: Education union pivots to address new situations caused by COVID-19 crisis. Education International. https://www.ei-ie.org/en/detail/16801/malaysia-education-union-pivots-toaddress-new-situations-caused-by-covid-19-crisis

- Ganapathy, M. (2016). Transformation of Malaysia's higher education system: Malaysia Education Blueprint (2015-2025). Bulletin of Higher Education Research. National Higher Education Research Institute, 5(1), 10-11.

- Mahathir, M. (2019). Education essential for nation's progress. https://www.nst.com.my/news/nation/2019/04/479436/dr-m-educationessential-nations-progress

- $\quad$ Reimers, F. M., \& Schleicher, A. (2020). A framework to guide an education response to the COVID-19 Pandemic of 2020. OECD. Retrieved April, 14, 2020. https://teachertaskforce.org/sites/default/files/2020-04/A framework to guide an education response to the COVID-19 Pandemic of 2020.pdf

- Surma, T., \& Kirschner, P. A. (2020). Virtual special issue computers in human behavior technology enhanced distance learning should not forget how learning happens. Computers in Human Behavior, 110, 106390.

- UNESCO. (2020). COVID-19 Educational disruption and response. In UNESCO. https://en.unesco.org/covid19/educationresponse

- World Bank. (2020). Remote Learning, EdTech \& COVID-19. World Bank. https://www.worldbank.org/en/topic/edutech/brief/edtech-covid-19

- World Economic Forum. (2020). How has COVID-19 affected Oman's plans for a post-hydrocarbon future? World Ecomomic Forum. 
https://www.weforum.org/agenda/2020/06/how-has-covid-19-affectedomans-plans-for-a-sustainable-economic-future/ 